\title{
Evaluation of Six Modern Varieties of Potatoes for Yield, Plant Growth Parameters and Resistance to Insects and Diseases
}

\author{
Touria E. Eaton ${ }^{*}$, Abul Kalam Azad², Humayun Kabir², Abu Bakkar Siddiq² \\ ${ }^{1}$ Cooperative Extension and Research, Lincoln University of Missouri, Jefferson City, MO, USA \\ ${ }^{2}$ Department of Crop Science \& Technology, Rajshahi University, Rajshahi, Bangladesh \\ Email: *EatonT@LincolnU.edu
}

How to cite this paper: Eaton, T.E., Azad, A.K., Kabir, H. and Siddiq, A.B. (2017) Evaluation of Six Modern Varieties of Potatoes for Yield, Plant Growth Parameters and Resistance to Insects and Diseases. Agricultural Sciences, 8, 1315-1326. https://doi.org/10.4236/as.2017.811095

Received: October 27, 2017

Accepted: November 27, 2017

Published: November 30, 2017

Copyright $\odot 2017$ by authors and Scientific Research Publishing Inc. This work is licensed under the Creative Commons Attribution International License (CC BY 4.0).

http://creativecommons.org/licenses/by/4.0/

\begin{abstract}
Six modern varieties of potatoes (Diamant, Cardinal, Granola, Felsina, Provento and Asterix) were investigated for their growth parameters and yield to determine their suitability for production in Bangladesh. Results indicate significant variations among the varieties in the yield and morphological characteristics and no difference in the number of main stems per hill. Among the six studied varieties, Asterix produced the greatest yield $(29.60 \mathrm{t} / \mathrm{ha})$, the greatest number of tubers per hill (13 tubers/hill), the largest percentage (84\%) of medium sized tubers (28 - $55 \mathrm{~mm}$ diameter), and the greatest plant height $(61.33 \mathrm{~cm})$. Diamant performed second after Asterix with a yield of $28.33 \mathrm{t} / \mathrm{ha}$, and a plant height of $59.0 \mathrm{~cm}$. Felsina produced the lowest yield (25.13 t/ha) and the lowest number of tubers per hill (8.67 tubers/hill). In a farmers' perception study, where farmers scored the yield and resistance to diseases and insect damage of the six varieties, from 1 to 6 ( 6 being the highest and 1 being the lowest), Asterix was the most preferred variety by farmers with scores of 6, 5.67 and 5.83 for yield, disease resistance and insect resistance respectively. Provento was the least preferred by farmers with a score of overall performance of 4 . The results of this study indicate that Asterix and Diamant have the potential to be grown successfully by the farmers in Bangladesh.
\end{abstract}

\section{Keywords}

Potato Cultivars, Vegetative Parameters, Yield Potentials, Farmers' Condition

\section{Introduction}

According to the Bangladesh Bureau of Statistics, potato production in Bangla- 
desh has increased from 10.85 ton/ha in 1992 to 19.9 ton/ha in 2016, making it the $4^{\text {th }}$ most important food crop in the country after rice, maize, and wheat [1]. In 2016, the country produced 9.47 million tones of potatoes, making Bangladesh the $7^{\text {th }}$ largest potato producer in the world [1]. Potato also contributes $55 \%$ of the total vegetable production in Bangladesh [2]. This increase of potato production is due to its easy production in various climatic conditions [3]. In fact, potato ranks third in the world's production and consumption after wheat and rice, which rank first and second respectively [4]. It grows well and is considered a staple food in at least 40 countries around the world [5]. The increase in Bangladesh production of potato is also due to its high yield $(16,540 \mathrm{~kg} / \mathrm{ha}$ in potato, $3,600 \mathrm{~kg} / \mathrm{ha}$ in rice and $2,400 \mathrm{~kg} / \mathrm{ha}$ in wheat) [6], and to its high nutritional value. With a concentration of $2.1 \%$ protein, one serving of potato provides as much protein as one serving of wheat $(7.5 \mathrm{~g} / \mathrm{serving})$ and more protein per serving than rice (5.2 g/serving) [7]. Potato is also rich in vitamin C and $\mathrm{B}$, minerals, and amino acids (leucine, tryptophan and isoleucine) [7] [8].

Despite the increase in production, the yield of potatoes in Bangladesh is still lower than that in other countries [9]. In 2006, potato yield in Bangladesh was 14.38 tons/ha compared to $35.27 ; 36.57 ; 40.05 ; 40.20$; and 44.10 tons/ha in Denmark, Germany, Netherlands, France, and the United States of America (USA) respectively, for the same year [10] [11]. One of the reasons causing this low yield of potato in Bangladesh is the use of low yielding varieties, the low resistance of these varieties to insects and diseases, and the lack of availability of quality seed tubers [12] [13]. Therefore the objective of this study was to evaluate six new and imported varieties of potato for yield and resistance to diseases and insects under the climatic conditions of Bangladesh. Other varieties and some of the varieties investigated in this project were studied by other investigators [14]-[20]. The investigators reported great plant height in Diamant and Cardinal; great number of main stems per hill in Ajax, Famosa, Elvira, Mirka and Cardinal; great tubers' weight per hill in Kufri Dewa; and great tubers' yield per hectare in Granola. This study aims to study the six varieties together for comparative results on plant height, number of main stems per hill, number of tubers per hill, tubers' weight per hill and tubers' yield per hectare. The goal is to determine which variety (or varieties), among the investigated varieties, is best in most of the criteria of interest and is therefore recommended for production in Bangladesh.

\section{Materials and Methods}

\subsection{Background Information on the Study Site}

The experiment was conducted at the Domar Foundation Seed Potato Production Farm, Bangladesh Agricultural Development Corporation (BADC) in Nilphamari. The site was located in North of Bangladesh $\left(24^{\circ} 22^{\prime}\right.$ North latitude, $88^{\circ} 35^{\prime}$ East longitude, and $18.6 \mathrm{~m}$ altitude).

The soil is classified as Active Teesta Flood Plain [21]. The texture of the soil 
is sandy, with an average $\mathrm{pH}$ of 5.6. The climate is subtropical monsoon characterized by three seasons: a hot and humid summer from March to June, a cool and rainy monsoon season from June to October, and a cool and dry winter from October to March. The most favorable season for growing potato at the site is winter. Therefore the experiment was conducted from December 8, 2008 to March 5, 2009. The mean maximum and minimum temperatures were $29^{\circ} \mathrm{C}$ and $9^{\circ} \mathrm{C}$ respectively, during that period. The mean relative humidity, wind speed, daily sunshine, total precipitation and total evaporation were 57\%, $1.26 \mathrm{~m} / \mathrm{s}, 6.19$ $\mathrm{h} /$ day, $31 \mathrm{~mm}$ and $51 \mathrm{~mm}$ respectively.

\subsection{Plant Material}

Six Dutch varieties of potato were selected for this study: Diamant and Provento, supplied by co-operative Agrico; Asterix and Felsina, supplied by Bluemoon International; and Cardinal and Granola, supplied by Tuber Crops Research Centre (TCRC) of Bangladesh Agricultural Research Institute (RARI).

Medium sized seed tubers (28 - $55 \mathrm{~mm}$ ) were placed in heated trays in BADC. They were ventilated and treated with defused light to enhance sprouting. The ventilation units were used for passing air and light for 10 days, and were placed at the upper side of the cold storage side wall, at $8 \mathrm{ft}$ intervals. Warm air was supplied for heating potato tubers.

When the sprouts of the tubers were about $2.5 \mathrm{~cm}$ (12 days after the beginning of the sprouting enhancement period), the sprouted tubers were treated with Provax ( $3 \mathrm{~g} / \mathrm{kg}$ seed) to control seed borne diseases and prepare the seed tubers for planting.

\subsection{Experimental Design}

The experiment was laid out in a randomized complete block split-plot design, with six potato varieties as the main plots. Individual plots $(3 \mathrm{~m} \times 3 \mathrm{~m})$ consisted of 6 raised beds $3 \mathrm{~m}$ long and $0.4 \mathrm{~m}$ wide. A spacing of $60 \mathrm{~cm}$ was maintained between rows and the potato seeds were placed $20 \mathrm{~cm}$ apart within the rows. A $0.5 \mathrm{~m}$ space was left between the plots. Thirty six potato seeds, from each of the 6 varieties, were planted in each block with a total of 6 plots and 216 sample plants. Blocks were $20.5 \mathrm{~m}$ long and $3 \mathrm{~m}$ wide. The blocks were replicated 6 times.

\subsection{Plant Cultivation, Fertility Management, and Pest Control}

Manure and fertilizers were applied to the experimental land based on the soil test analysis and the recommendations of the Domar Foundation Seed Potato Production Farm. Before final land preparation, Cowdung and Mustard oilcake were broadcasted in each plot at the rate of $5,443 \mathrm{~kg} / \mathrm{ha}$ and $50 \mathrm{~kg} / \mathrm{ha}$ respectively. Gypsum $\left(\mathrm{CaSO}_{4}\right)$, Magnesium Sulfate $\left(\mathrm{MgSO}_{4}\right)$, Zinc Sulfate $\left(\mathrm{ZnSO}_{4}\right)$ and Boric acid $\left(\mathrm{H}_{3} \mathrm{BO}_{3}\right)$ were broadcasted and incorporated, during land preparation, at the respective rates of $98 ; 98 ; 15$ and $7 \mathrm{~kg} / \mathrm{ha}$ as recommended by the soil test- 
ing laboratory. Recommended rate $(247 \mathrm{~kg} / \mathrm{h})$ of Triple Super Phosphate (TSP) $\left(\mathrm{CaH}_{4} \mathrm{P}_{2} \mathrm{O}_{8}\right)$ and half recommended rate of Urea $\left(\mathrm{CH}_{4} \mathrm{~N}_{2} \mathrm{O}\right)(148 \mathrm{~kg} / \mathrm{h})$ were sidedressed, in furrows on both sides of the seed beds and mixed with the soil. The remaining portion of the urea was side-dressed and mixed with the soil 35 days after planting. The plots were flood irrigated and manually weeded as needed.

To prevent infestation with Late blight and aphids, plants were sprayed with Ridomil gold ( $2 \mathrm{~g} / \mathrm{L}$ water) and Metasystox ( $2 \mathrm{~g} / \mathrm{L}), 35$ days after planting.

\subsection{Harvesting}

Haulms were pulled manually at the maturity level, 80 days after planting. The tubers were kept underground for 10 more days for skin hardening, and then harvested manually.

\subsection{Data Collection (Plant Height, Number of Stems per Plant, Number of Tubers per Plant, and Yield)}

Ten hills from each plot were randomly selected for data collection of plant height, number of stems per plant and number of tubers per plant. Plant height was measured from the base of the plant to the terminal bud. Tubers collected from each plot ( 90 plants in $9 \mathrm{~m}^{2}$ ) were weighed, in $\mathrm{kg}$, for yield determination in $\mathrm{kg} / \mathrm{ha}$. The weight obtained per $9 \mathrm{~m}^{2}$ was then converted to $\mathrm{kg} / \mathrm{ha}$. The values were averaged and used in the statistical analysis.

\subsection{Tuber Grade}

Once weighed, the tubers collected from each plot were sorted and classified into three grades: grade $\mathrm{C}$ potatoes with a diameter less than $28 \mathrm{~mm}$, grade $\mathrm{B}$ potatoes with a diameter between 28 and $55 \mathrm{~mm}$, and grade A potatoes with a diameter greater than $55 \mathrm{~mm}$. Potatoes from each grade and plot were weighed $(\mathrm{Wg}) . \mathrm{Wt}$ is the weight of all tubers from the same plot. To determine the percentage of potatoes of each grade within a plot, the following formula was used: $\%$ of potatoes grade $\mathrm{M}=\left(\mathrm{Wg}_{\mathrm{M}} / \mathrm{Wt}\right) \times 100 . \mathrm{M}=$ Grade $\mathrm{A}, \mathrm{B}$, or C. For each plot, the sum of the percentages of all grades equals 100 .

\subsection{Farmers' Preference}

In Bangladesh, farmers' participatory research of different crops was recently introduced by Bangladesh Agricultural Research Institute (BARI) to help farmers determine their preferred varieties that are suitable for their own plant growth conditions and socio-economic criteria. The BARI collects and processes the data on farmers' preferences and disseminates the results to other farmers so they make informed decisions on variety selection of crops.

In this experiment, varieties of potato, at the vegetative stage, were evaluated by 30 potato growers. The thirty farmers were divided into six groups of five farmers. Every group of farmers scored the potato plants based on the number of stems per plant, leaf characteristics, disease and insect resistance, expected yield 
and overall preference. The scores ranged from one to six with six indicating the best variety for a particular criteria and one indicating the worst variety for the criteria. Scores' data were then collected and statistically analyzed.

\subsection{Statistical Analysis}

The data obtained on the plant growth parameters, yield, and farmers' preferences, was processed by analysis of variance (ANOVA) using MSTAT-C program [22]. The significance of differences among the treatments' means were evaluated by least significant difference (LSD) test $(P=0.05)$. Mean of the treatments were separated with Duncan's New Multiple Range Test at $P=0.05$ [23].

\section{Results and Discussion}

\subsection{Plant Height}

The statistical analysis indicates significant variations among the potato varieties in respect of plant height (Table 1). Asterix and Diamant produced the tallest plants ( 61.33 and $59 \mathrm{~cm}$ respectively), followed by Provento, Felsina, and Cardinal (54.83, 53.83, and $53.3 \mathrm{~cm}$ respectively). Granola produced the shortest plants $(51.17 \mathrm{~cm})$. These differences in plant height among the varieties may be caused by plant genetics and the quality of the plant material. No statistical differences in plant height were found among Cardinal, Granola and Felsina, or between Diamant and Provento.

Our results are similar to those reported by other investigators [14] [15] and [16]. Hossain et al. [15] found taller plants $(56-60 \mathrm{~cm})$ in the varieties Ajax, Estima, Diamant and Nicola. In another experiment, Hossain et al. [16] reported greater height $(60-68 \mathrm{~cm})$ in Ajax, Famosa, Elvira, Mirka and Cardinal.

\subsection{Number of Main Stems per Hill}

The number of stems per hill ranged from 4.67 to 6.17 among varieties, and was not statistically different from one variety to the other (Table 1). Numerically maximum number of main stems per hill was produced in Asterix (6.17) followed by Granola (5.5), and Diamant (5.17). Lowest number of stems per hill (4.67) was found in Cardinal, Felsina and Provento.

Our results are similar to those reported by Bashar [14]. Cardinal was reported to produce 5.2 main stem per hill [14]. Diamant was reported to produce 5.17 main stems per hill [17].

\subsection{Number of Tubers per Hill}

There were significant differences in the number of tubers per hill among varieties (Table 1). Asterix, generating the greatest number of stems per hill (13 stems/hill), was not significantly different from Granola (10.83 stems/hill), but was significantly different from all the other varieties: Felsina (8.67), Diamant (9.67), Cardinal (9.67) and Provento (9.83) (Table 1). 


\subsection{Tubers' Weight per Hill}

Significant variations were observed, in tuber weight per hill, among the varieties (Table 1). In general the average weight ranged from $375 \mathrm{~g}$ to $443.80 \mathrm{~g}$. The highest weight of tubers per hill was generated by Asterix ( $443.80 \mathrm{~g}$ ), which was not statistically different from that of Diamant, Cardinal and Granola, with a weight/hill of 424.80, 405.00, and 420.00 g respectively. Felcina and Provento were not statistically different and exhibited the lowest weigh/hill among all varieties.

Variation among different varieties, in regard to the weight of tubers per plant, may be due to the genetics, the management practices, the seed quality, or the agro-ecological conditions of the experimental sites. Carrasco et al. [19] found an average weight of tubers per plant of $350 \mathrm{~g}$ and $570 \mathrm{~g}$ in $\mathrm{F}_{70021}$ and Viking respectively. The varieties Kufri Dewa and Diamant were found to generate a weight of $440.3 \mathrm{~g}$ and $406 \mathrm{~g}$ respectively [20].

\subsection{Tuber Yield per Hectare}

Significant variations, in yield of tuber per hectare, were observed among the varieties investigated in this experiment (Table 1). The variety Asterix showed the highest yield (29.60 t/ha), which was not statistically different from that of Diamant, Cardinal and Granola, with a yield of 28.33; 27.00; and 28.00 t/ha respectively. Felsina and Provento exhibited the lowest yield of 25.13 and $25.40 \mathrm{t} / \mathrm{ha}$, among all varieties, but were not statistically different from Cardinal and Granola (Table 1).

In our study, the variety Diamant generated a higher yield than that reported by numerous investigators. A yield of 23.43; 22.3; 26.5; and $22.81 \mathrm{t} / \mathrm{ha}$ was reported by Ahmad [24], Anonymous [25] [26] and Hossain et al. [27] respectively.

Our findings are different from those reported by Shafayet et al. [28], who found that a highest yield was observed in Granola (27.82 $\mathrm{t} / \mathrm{ha}$ ) followed by Asterix (26.83 t/ha) and Provento (26.33 t/ha).

Table 1. Means of yield and plant growth parameters of six modern varieties of potato.

\begin{tabular}{cccccc}
\hline $\begin{array}{c}\text { Name of the } \\
\text { varieties }\end{array}$ & $\begin{array}{c}\text { Plant height } \\
(\mathrm{cm})\end{array}$ & $\begin{array}{c}\text { Number of main } \\
\text { stems per hill }\end{array}$ & $\begin{array}{c}\text { Number of } \\
\text { tubers per hill }\end{array}$ & $\begin{array}{c}\text { Tuber yield } \\
\text { per hill }(\mathrm{g})\end{array}$ & $\begin{array}{c}\text { Tuber yield per ha } \\
\text { (ton) }\end{array}$ \\
\hline Diamant & $59.0 \mathrm{ab}$ & 5.17 & $9.67 \mathrm{~b}$ & $424.80 \mathrm{a}$ & $28.33 \mathrm{a}$ \\
Cardinal & $53.3 \mathrm{c}$ & 4.67 & $9.67 \mathrm{~b}$ & $405.00 \mathrm{abc}$ & $27.00 \mathrm{ab}$ \\
Granola & $51.17 \mathrm{c}$ & 5.50 & $10.83 \mathrm{ab}$ & $420.00 \mathrm{ab}$ & $28.00 \mathrm{ab}$ \\
Felsina & $53.83 \mathrm{c}$ & 4.67 & $8.67 \mathrm{~b}$ & $375.00 \mathrm{c}$ & $25.13 \mathrm{~b}$ \\
Provento & $54.83 \mathrm{bc}$ & 4.67 & $9.83 \mathrm{~b}$ & $380.67 \mathrm{bc}$ & $25.40 \mathrm{~b}$ \\
Asterix & $61.33 \mathrm{a}$ & 6.17 & $13.00 \mathrm{a}$ & $443.80 \mathrm{a}$ & $29.60 \mathrm{a}$ \\
CV(\%) & 7.39 & 12.43 & 10.05 & 8.89 & 8.93 \\
\hline
\end{tabular}

Means followed by different letters within columns are significantly different by Duncan's new multiple range test $(\mathrm{P}=0.05)$. 
This differences in the yield among varieties might be related to the genetic, the quality of the potato seed, or to better adaptability of the variety to the climatic conditions of the experimental site.

\subsection{Grade of Tubers (by Weight Percentage)}

Medium sized (28 - $55 \mathrm{~mm}$ diameter) (Grade B) tubers are desirable for better storage. Significant variations, among the six varieties, were observed in the production percentage (by weight) of different grades of tubers.

The percentage of Grade B potatoes (Figure 1) was higher, in all the varieties, than the percentage of Grade A or Grade C potatoes. The range of the weight of Grade B tubers was between $67.8 \%$ and $84.2 \%$ of total weight of all grades of the same variety. The highest percentage of Grade B tubers was produced by the variety Asterix (84.2\%) followed by Felsina (75.2\%), Granola (72.2\%), Cardinal (70.8\%), Provento (69.2\%) and Diamant (67.8\%) (Figure 2).

Regarding Grade C tubers, Diamant produced more Grade C tubers (24.40\%) than any of the other varieties (Figure 3). Cardinal, Provento, Granua, and Felsina produced a percentage of $23.20 ; 21.40 ; 20.20$ and $18.40 \%$ of Grade C tubers respectively. Asterix produced the smallest percentage (11\%) of Grade C tubers (Figure 3).

The highest percentage (11.80\%) of Grade A tubers was produced by Diamant

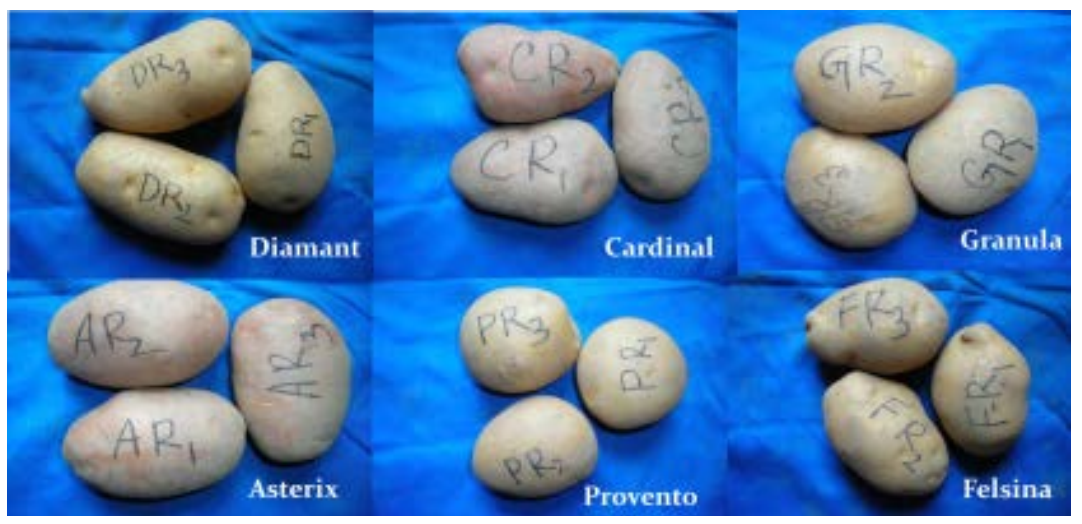

Figure 1. Medium sized potatoes of all varieties.

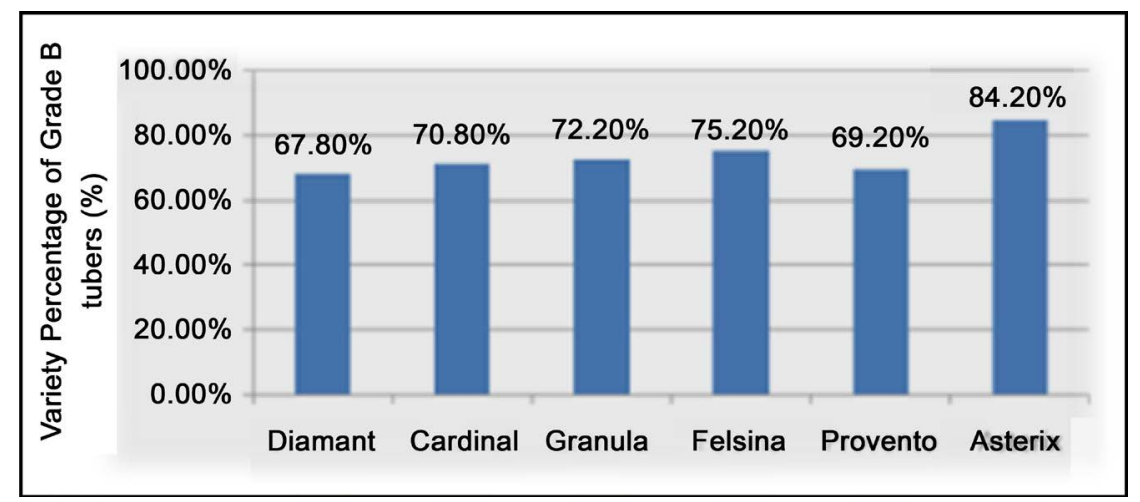

Figure 2. Variations among varieties in the percentage of Grade B tubers. 


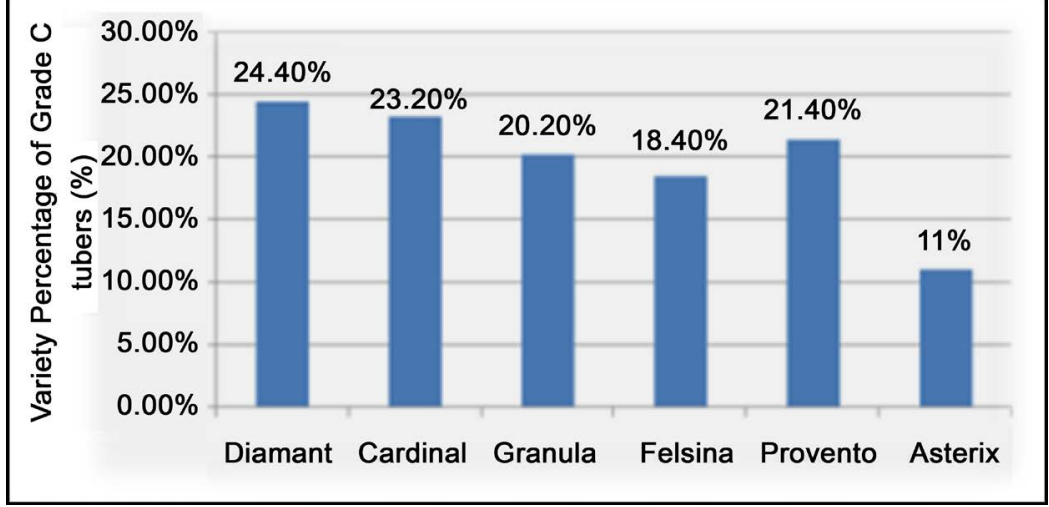

Figure 3. Variations among varieties in the percentage of Grade C tubers.

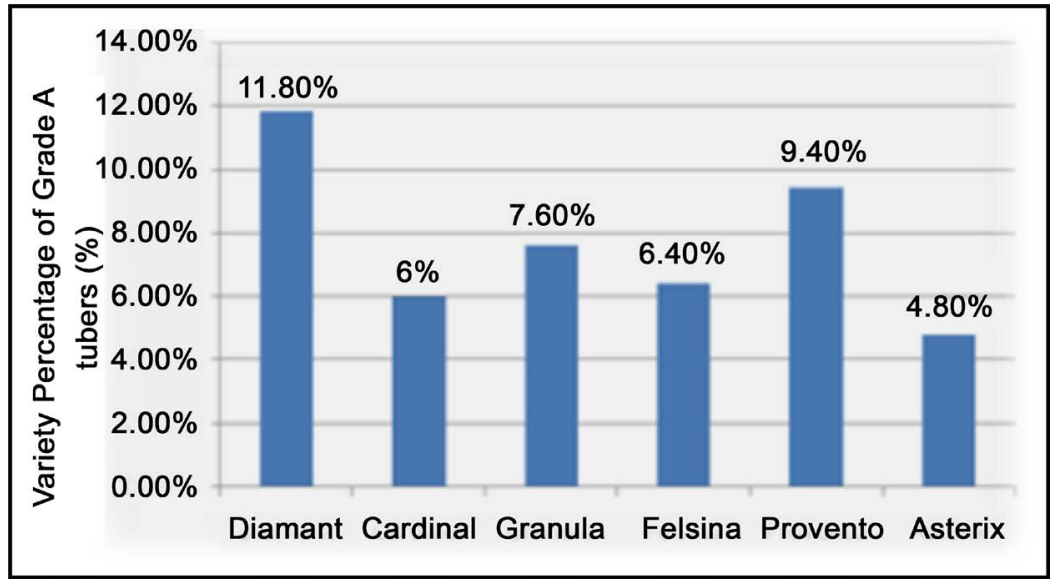

Figure 4. Variations among varieties in the percentage of Grade A tubers.

(Figure 4). Provento, Granula, Felsina, and Cardinal produced a percentage of 9.40\%, 7.60\%, 6.40\% and 6\% of Grade A tubers respectively (Figure 4). Asterix generated to lowest percentage of grade A potatoes (4.8\%) (Figure 4).

Hossain et al. [29] reported that the varieties Elvira and Patrones produced a percentage of $77 \%$ to $80 \%$ Grade B potatoes.

These differences, in the percentage of different grades, among varieties might be due to the adaptability of the variety to the climatic conditions of the experimental site, the genetics of the variety or the quality of the potato seed.

\subsection{Farmers' Preference}

Participation of the farmers in this study was very useful in identifying the varieties that are preferred by the farmers. This farmers' participation will help farmers adopt the new profitable varieties instead of land races, old or obsolete varieties [30]. Significant differences were found among the scores of farmers' preference on different traits of the varieties (Table 2).

Highest scores on plant height was obtained in Asterix (6.00) followed by Cardinal (5.00). No statistical difference was found among Diamant (4.67), Granola (4.50), Felsina (4.33) and Provento (4.17); or among Diamant, Granola, 
Table 2. Farmers' preferences: Scores of different traits of six modern varieties of potato at the vegetative stage, during the experimental period.

\begin{tabular}{ccccccc}
\hline \multirow{2}{*}{ Variety } & \multicolumn{5}{c}{ Farmers' scores } \\
\cline { 2 - 7 } & Plant height & Leaf & Disease & Insect & Expected yield & Overall performance \\
\hline Diamant & $4.67 \mathrm{bc}$ & $5.33 \mathrm{a}$ & $4.33 \mathrm{~b}$ & $5.50 \mathrm{ab}$ & $4.83 \mathrm{bc}$ & $4.67 \mathrm{bc}$ \\
Cardinal & $5.00 \mathrm{~b}$ & $4.67 \mathrm{~b}$ & $4.50 \mathrm{~b}$ & $5.00 \mathrm{bc}$ & $5.00 \mathrm{~b}$ & $5.00 \mathrm{~b}$ \\
Granola & $4.50 \mathrm{bc}$ & $4.67 \mathrm{~b}$ & $5.00 \mathrm{ab}$ & $5.00 \mathrm{bc}$ & $4.00 \mathrm{~d}$ & $4.33 \mathrm{~cd}$ \\
Felsina & $4.33 \mathrm{c}$ & $4.00 \mathrm{c}$ & $4.83 \mathrm{~b}$ & $4.83 \mathrm{c}$ & $4.5 \mathrm{bcd}$ & $4.67 \mathrm{bc}$ \\
Provento & $4.17 \mathrm{c}$ & $5.33 \mathrm{a}$ & $4.67 \mathrm{~b}$ & $5.33 \mathrm{abc}$ & $4.33 \mathrm{~cd}$ & $4.00 \mathrm{~d}$ \\
Asterix & $6.00 \mathrm{a}$ & $5.50 \mathrm{a}$ & $5.67 \mathrm{a}$ & $5.83 \mathrm{a}$ & $6.00 \mathrm{a}$ & $5.83 \mathrm{a}$ \\
CV (\%) & 10.63 & 10.95 & 13.09 & 10.49 & 10.90 & 11.34
\end{tabular}

Means followed by different letters within columns are significantly different by Duncan's new multiple range test $(\mathrm{P}=0.05)$

Felsina and Provento (Table 2). In regard to plant height, Provento scored lowest among all varieties, followed by Felsina, Granola and Diamant. Asterix scored the highest.

The variety Asterix (5.50) got the highest preference in regard to leaf characteristics, and was not statistical different from Diamant (5.33), nor Provento (5.33). No statistical difference was found between Cardinal (4.67) and Granola (4.47). Felsina (4.00) was the least preferred variety by farmers, in term of leaf characteristics.

In regard to resistance to diseases, Asterix (5.67) scored the highest, and was not statistically different from Granola. No statistical difference was found among Diamant, Cardinal, Granola, Felsina, and Provento.

Regarding resistance to insects, Asterix (5.83) scored the highest, and was not statistically different from Diamant (5.50) or Provento (5.33). No statistical difference was found among Diamant, Cardinal, Granola and Provento. Also, no statistical difference was found among Cardinal, Granola, Felsina and Provento. Felsina (4.83) scored the lowest in terms of resistance to insect damage.

Significant differences were found among the varieties in terms of expected yield. Asterix (6) scored the highest, followed by Cardinal (5.0). No statistical difference was found among Cardinal, Diamant and Felsina, among Diamant, Felsina and Provento, and among Granola, Felsina, and Provento. Granola (4.00) scored lowest in expected yield among the varieties.

On the basis of all the characteristics of potato plant, Asterix (5.83) was ranked first, followed by Cardinal (5.0). No statistical difference was found between Diamant (4.47), Cardinal (5.00), and Felsina (4.67), among Diamant, Granola, and Felsina, or between Granola and Provento (4). Provento was the least preferred variety of potato by farmers.

\section{Conclusions}

Our results indicate that Asterix potato is a good candidate for production in 
Bangladesh. It produced the tallest plant, the greatest number of tubers per hill, the greatest weight of tubers by hill and the highest yield. It also produced the greatest percentage of medium sized potatoes and is resistant to insects and diseases, per comparison to the other varieties. Asterix also is the most favorite variety by farmers. Felsina and Provento, on the other hand, exhibited small plants, low weight of tubers per hill, and low yield, per comparison to the other varieties. They also have low resistance to diseases and insects compared to Asterix, and they are the least favorite varieties, among the investigated varieties, by farmers.

Because of its large plants, high yield and high resistance to insects, Diamant can do well, under the growth conditions of Bangladesh, with some disease management regime, as its resistance to diseases is low.

It is thus recommended that farmers in Bangladesh grow Asterix for its high yield and resistance to diseases and insects. Diamant is the second best candidate for potato production in Bangladesh if disease management tools are available.

\section{Limitation of the Study}

The varieties studied in this project were new and their production duration was not known according to our research. All tubers were harvested at the same time. Some of the varieties may have needed to be harvested earlier or later than the time of harvest used. Harvesting tubers earlier than needed may affect tubers' weight per hill and tubers' yield per hectare.

\section{References}

[1] Baral, B. (2016) Bangladesh Bureau of Statistics (BBS). Statistics and Informatics Division (SID), Ministry of Planning.

[2] MOA. (2009) Hand Book of Agricultural Statistics. Market Monitoring and Information System, Ministry of Agriculture (MOA), Govt. People's Repub. Bangladesh, $493 \mathrm{p}$.

http://bbs.portal.gov.bd/sites/default/files/files/bbs.portal.gov.bd/page/cdaa3ae6_cb 65_4066_8c61_d97e22cb836c/National_Accounts_Blue_Book_2016.pdf

[3] Gupto, V.K., Luthra, S.K. and Singh, B.P. (2015) Storage Behaviour and Cooking Quality of Indian Potato Varieties. Journal of Food Science and Technology, 52, 4863-4873. https://doi.org/10.1007/s13197-014-1608-Z

[4] Thompson, H.C. and Kelly, W.C. (1957) Vegetable Crops. McGraw Hill Book Company Inc., New York.

[5] Islam, M.T. (1987) An Economic Study of Potato Preservation in Cold Storage in Some Selected Areas of Bangladesh. Unpublished M.Sc. Thesis Submitted to the Department of Cooperation and Marketing, Bangladesh Agricultural University, Mymensingh, Bangladesh.

[6] Ahmad, K.U. (1974) Status of Potato Research in Bangladesh. Horticultural Research Notes No. 15, Div Hort, BARI, Joydebpur, Dacca, 16 p.

[7] Potato, Baked, Flesh and Skin without Salt Nutrition Facts and Calories. http://nutritiondata.self.com/facts/vegetables-and-vegetable-products/2770/2

[8] Khurana, P.S.M. and Naik, P.S. (2003) The Potato: An Overview. In the Potato 
Production and Utilization in Sub-Tropics. In: Paul Khurana, S.M., Minas, J.S. and Pandy, S.K., Eds., Mehta Publication, New Delhi, 1-14.

[9] BBS (2010) Statistical Year Book, 2009-2010. Bangladesh Bureau of Statistics (BBS), Dhaka.

[10] Pandey, S.K. (2007) Approaches for Breaching Yield Stagnation in Potato. Potato Journal, 34, 1-9.

[11] Forecast Working Group "Potatoes". 2010. Working Document. AGRI.C.2/POTATOES8/10.

https://ec.europa.eu/agriculture/sites/agriculture/files/fruit-and-vegetables/productreports/potatoes/expert-group/potatoes-2010-12_en.pdf

[12] Hossain, M., Hossain, M.I. and Dey, T.K. (2010) Disease Free Seed Potato Production through Seed Plot Technique at Farm Level. Annual Report 2009-10, Tuber Crops Research Centre, BARI, Joydebur, Gazipur, 147 p.

[13] Chowdhury, E.H. and Rasul, M.G. (1995) True Potato Seed Research and Development in Bangladesh. Proceedings of the Workshop on National Programme for True Potato Seed in Bangladesh, BARC, Dhaka, 28-37.

[14] Bashar, M.A. (1978) Testing Six Varieties of Potato at Jaintiapur. Proceedings of the 1 st Workshop of Potato Research Workers, PRC, BARI, Joydebpur, Dacca, 30-31.

[15] Hossain, M.A.E., Khan, A.I., Rahman, M. and Rahman, A. (1980) Performance of Potato Varieties in Their 1st Generation. Proceedings of the 3rd Workshop of Potato Research Workers, PRC, BARI, Joydebpur, Dhaka, 13-15.

[16] Hossain, M.A.E., Rahman, M. and Rashid, H. (1982) Performance of Potato Varieties in Their 1st Generation. Proceedings of the 3rd Workshop of Potato Research Workers, PRC, BARI, Joydebpur, Dhaka, 15-17.

[17] Hoque, M.A. (1993) Evaluation of Exotic Potato Varieties in Second Generation. Annual Report, TCRC, BARI, Joydebpur, Gazipur, Bangladesh, 8-13.

[18] Quasem, M.A. (1970) A Study on the Performance of Eighteen Potato Varieties of the Netherlands. M.Sc. Thesis, Bangladesh Agricultural University, Mymensingh, $18-60$.

[19] Carrasco, A., Zamora, N. and Quercen, L. (1985) Comparison of 7 Potato (Solanum tuberosum) Cultivars during 3 Seasons. Ciencia y Tecnica en la Agricultura. Hortalizas, Papa, Granos y fibras, 4, 91-102. [Cited from Potato Abstracts, 12(1): 28 (1987)]

[20] Anonymous (1986) Study on the Comparative Performance of Some Exotic Varieties of Potato. Annual Report, PRC, BARI, Joydebpur, Gazipur, Bangladesh, 29-30.

[21] BARC (2005) Fertilizer Recommendation Guide. Bangladesh Agricultural Research Council. New Airport Road, Farmgate, Dhaka, 149 p.

[22] Steel, R.G.D. and Torrie, J.H. (1980) Principles and Procedures of Statistics. A Biometrical Approach. 2nd Edition, McGraw-Hill, New York, 20-90.

[23] Duncan, D.B. (1955) Multiple Ranges and Multiple F-Test. Biometrics, 11, 1-42. https://doi.org/10.2307/3001478

[24] Ahmad, K.U. (1980) Exotic Potato Varieties for Bangladesh. Proceedings of the 3 rd Workshop of Potato Research Workers, PRC, BARI, Joydebpur, Dhaka, 1-12.

[25] Anonymous (1992) Variety Development from Exotic Sources. Annual Report, TCRC, BARI, Joydebpur, Gazipur, Bangladesh, 21-52.

[26] Anonymous (1987) Evaluation of Exotic Potato Varieties in Their First, Second and Third Generation. Annual Report, TCRC, BARI, Joydebpur, Gazipur, Bangladesh, 
1-20.

[27] Hossain, M.M., Rashid, M.H., Sattar, M.A. and Akhter, M.I. (2003) Preliminary Yield Trial (PYT) of Dutch Varieties in Their 1st Generation. Annual Research Reports on Tuber Crops Improvement, TCRC, BARI, Joydebpur, Gazipur, 9-10.

[28] Shafayet, H., Golam, R., Khaleque, A.M, Moynul, H. and Mannan, A.K. (2015) Yield Potential of Twelve Potato (Solanum tuberosum) Varieties Grown from Different Generations of Seed. The Agriculturists, 13, 120-132.

[29] Hossain, A.Z., Khan, A.I. and Kabir, H. (1984) Performance of Exotic Potato Varieties in Their First Generation in the Year 1983-84. Proceedings of the 6th Workshop of Potato Research Workers, PRC, BARI, Joydebpur, Dhaka, 9-13.

[30] Joshi, A. and Witcombe, J.R. (1996) Farmers Participatory Crop Improvement. Participatory Varietal Selection: A Case Study in India. Experimental Agriculture, 32, 461-477. https://doi.org/10.1017/S0014479700001538 